Egypt. J. of Nutrition and Health Vol. 14 No. 2July (2019)

\title{
Study the Biological and Biochemical Effects of Some Dried Fruits on Acute Renal Failure in Rats
}

\author{
Ola Ibrahim El-Desoky Ali, Ensaf Mokhtar Yasen \\ and Asmaa Abdelaziz Temraz
}

\author{
Nutrition and Food Science Department, Faculty of Home Economics, \\ Al-Azhar University Tanta, Egypt.
}

\begin{abstract}
Golden berry and sweet cherry are known as nutritious fruit and herbal medicine for healthpromoting properties. This study was conducted to investigate the effect of golden berry and sweet cherry on acute renal failure in rats induced by glycerol. Thirty six male albino adult rats (150 $\pm 10 \mathrm{~g}$.) were used, divided into two main groups; one (6 rats each) was used as a negative control group, while the other group of rats were injected intramuscularly with glycerol $10 \mathrm{ml} / \mathrm{kg} \mathrm{BW}(50 \% \mathrm{v} / \mathrm{v}$ in sterile saline $0.9 \%)$ to induce acute renal failure. The second main group was divided into 5 equal subgroups ; one used as a positive control and the other four groups were fed on supplemented diet (5\% and $10 \%$ ) of each of dried golden berry and sweet cherry.Biological evaluation, liver enzymes, kidney functions, $\mathrm{Na}, \mathrm{K}$ and serum antioxidant markers were estimated at the end of the experiment. The results indicated that kidney and liver functions were restored significantly in groups of rats which received golden berry and sweet cherry $10 \%$, followed by golden berry and sweet cherry $5 \%$ as compared to the positive control group. Glycerol rats group showed significant decrease in serum proteins and serum electrolytes. On the other hand, all supplemented groups with golden berry and sweet cherry showed a gradual significant increase in the mentioned parameters. Therefore, this study reveals the benefits of golden berry and sweet cherry in experimental animals with kidney and liver disease.
\end{abstract}

Key words: Acute renal failure -glycerol - golden berry and sweet cherry.

\section{Introduction}

Golden berry (physalisperuviana L.), known locally in Egypt as harankash and known in English speaking countries as golden berry, has many medicinal and edible uses as a promising fruit (Ramadan, 2011). The benefits associated with the consumption of Physali speruviana L. (PP) are mainly due to their nutritional composition. It contains biologically active components that provide health benefits and reduce risk for certain diseases. Among its major components are its high amounts of polyunsaturated fatty acids, $\beta$ carotene, vitamins $B$, and $C$ and phytosterols, and the presence of essential minerals such as iron, vitamins such as $\mathrm{E}$ and $\mathrm{K}$, and with anolides (Puente et al., 2011). Physalisperuviana $L$. extracts showed antioxidant activity as well as anti-hepatotoxic effect, antiproliferative effects on hepatoma cells and anti-inflammatory activity. In addition, it has excellent potential as a food-based strategy as antidiabetes and antihypertension solutions (Chang et al., 2008). 


\section{Ola Ibrahim El-Desoky Ali, et al}

Sweet cherry is a product from the berry fruit of a North American green shrub. It is used as herbal medicine, Vaccinium macrocarpon is the Latin name of the Crain berry plant (Jacob et al., 2003).Phenolic compounds, as well as their health-promoting properties, also play a key role in cherry quality attributes since they contribute to colour, taste, aroma and flavor (Tomás-Barberán and Espín 2001). Sweet cherry polyphenols include phenolic acids (hydroxyl cinnamic and hydroxyl benzoic acids) and flavonoids (anthocyanins, flavonols and flavan-3-ols). (Viljevac et al., 2012). The highest levels of total polyphenolic compounds are found in the skin of sweet cherry fruits, followed by the flesh and pit (Chaovanalikit and Wrolstad 2004). Current epidemiological studies strongly support a contribution of polyphenols in the prevention of cardiovascular diseases, cancers, diabetes, insomnia, obesity and osteoporosis, as well as neuro degenerative diseases. A wide range of concentrations of total phenolic content (TPC) has been reported both in sweet and sour cherries(Serradilla et al., 2016).

Glycerol injection caused histopathological changes such as renal tubular injury and renal tubular myoglobin deposition. Levels of N. -(hexanoyl) lysine- modified, 4- hydroxyl -2 nonenalmodified and nitrotyrosine - modified proteins in rat kidneys were unaltered at 1 hour after glycerol injection induced acute kidney injury (Akina et al., 2016).

\section{Objective of the study}

This study was carried out to investigate the effect of golden berry and sweet cherry on acute renal failure induced by glycerol in rats.

\section{Materials and Methods}

\section{Materials:}

Golden berry and sweet cherry were obtained from local market, Tanta City El-Gharbia Governorate., Egypt. Glycerol, Casein, minerals, vitamins, and cellulose were obtained from ElFaroniah (Chemicals Company), Tanta, Egypt. Thirty six male albino rats (Sprague Dawely) Strain) were purchased from the laboratory animal house of faculty of science, Tanta University, Egypt.

Methods:

Dehydration:

Golden berry and sweet cherry were picked gently washed, carefully drained, dried in the oven at $50^{\circ} \mathrm{C}$ for $24 \mathrm{hr}$., crushed and stored in labeled polyethylene bags until analysis.

\section{Nutritional Characteristics Chemical Composition:}

Golden berry and sweet cherry were chemically analyzed for moisture, fat, crude protein, crude fiber, and ash, according to methods of (A.O.A.C., 2000). Total carbohydrates were estimated by difference. Whereas, the energy was calculated by the Atwater factor of 4,9 and 4 for each gram of proteins, fats, and carbohydrates, respectively(Chaney, 2006).

Minerals:

$\mathrm{Na}$ and $\mathrm{K}$ were extracted by wet acid-digestion method, using mixture of nitric acid and perchloric acid (HNO: $\mathrm{HClO}, 5: 1 \mathrm{w}: \mathrm{v}$ ). total $\mathrm{Na}$ and $\mathrm{K}$ in the digested solution were measured by atomic absorption spectrophotometry (Thermo Elmental, 300VA, UK) (Lindsey and Norwell, 1969). 


\section{Egypt. J. of Nutrition and Health Vol. 14 No. 2July (2019)}

Vitamin C and E Analysis:

Spectrophotometer was used to estimate vitamin C and E levels as described by

(Anonymous, 1966), where ascorbic acid reduced the dye of 2, 6 -dichlorophenolendophenol.

$\beta$-Carotene Analysis:

was analyzed by HPLC (reversed-phase) according to (Rodriguez-Amaya, 1997).

\section{Experimental Design:}

Thirty six male albino rats of Sprague Dawely strain weighing an average of (150 $\pm 10 \mathrm{~g})$ were used in the study. After the adaptation period of seven days, rats were randomly divided into two main groups; the first group which is the negative control had 6 rats that were fed on basal diet composed of $12 \mathrm{~g}$ of casein ( $85 \%$ protein); corn oil (10\% fat); minerals mixture (4\% minerals); vitamins mixture ( $1 \%$ vitamins); cellulose (4\% fiber); and corn starch (71\% starch)according to(Jerome et al., 2002); water supply was given ad-libitum and checked daily. The second group ( $n=30$ rats), were injected once intramuscularly with glycerol $(10 \mathrm{ml} / \mathrm{kg} \mathrm{BW}, 50 \% \mathrm{v} / \mathrm{v}$ in sterile saline) to induce acute renal failure, then they were divided into five subgroups; each group had 6 rats, one kept as a positive control and fed on basal diet, the other four groups were fed on basal diet supplemented with golden berry at $50 \mathrm{~g} / \mathrm{kg}$ and $100 \mathrm{~g} / \mathrm{kg}$ and sweet cherry at $50 \mathrm{~g} / \mathrm{kg}$ and $100 \mathrm{~g} / \mathrm{kg}$, respectively. Feeding experiment continued for four weeks. Golden berry and sweet cherry were added on the expense of corn starch

\section{Biological Evaluation:}

During the experimental period, feed intake, body weight gain (BWG \%), and feed efficiency ratio (FER) were recorded every week. After being sacrificed organ weight relative to body weight \% were calculated as described by Chapman et al., (1959). Liver, spleen, kidney and heart were removed from each rat, carefully washed with saline solution, dried with filter paper and weighed based on Drury and Wallington (1980).

\section{Biochemical Analysis:}

At the end of the experiment rats were fasted overnight prior to sacrificing under anesthesia. Blood samples were collected from the hepatic portal vein. Each sample was placed in a dry clean centrifuge tube. To separate the serum, blood samples were centrifuged for $10 \mathrm{~min}$. at 3000 revolutions per minute. Serum was carefully separated into dry, clean Wasserman tubes using a Pasteur pipette, then kept frozen at $-20 \mathrm{C}^{\circ}$ till analysis. The analysis was performed at the Medical College Laboratory, El-Zgazig University, Egypt. Serum uric acid was measured by the method described of Fossati et al., (1980), whereas urea nitrogen was determined in the serum based on Patton and Crouch (1977). Serum creatinine analysis was followed by the method described by Faulkner and King, (1976),Serum total protein (T.P) was estimated by Biuret reaction as described by Sonnenwirth and Jaret (1980).Serum albumin (Alb)was determined according to the method described by Drupt, (1974) by using Diamond company kit. Serum globulin (Glb)was calculated using equation (1) according to Chary and Sharma (2004).Serum Alb / Glb ratio (A/G) was calculated using equation (2) according to Srivastava et al.,(2002)

Serum globulin $(\mathrm{g} / \mathrm{dl})=$ total protein $(\mathrm{g} / \mathrm{d})$ - Albumin $(\mathrm{g} / \mathrm{dl})$. Eq. (1) Alb / Glb ratio = Serum albumin (g/dl) / Serum globulin (g/dl).Eq. (2)

Serum sodium and potassium were determined by the colorimetric method described by Henry (1974).Serum aspartate amino transaminase (AST), alanine amino transaminase (ALT) activities were determined as mentioned in Reitman and Frankel., (1957). Superoxide dismutase 


\section{Ola Ibrahim El-Desoky Ali, et al}

(SOD) activity was determined by the method of Kakkar et al., (1984).Malondialdehyde (MDA) was determined by the method of Okhawa et al., (1979).

\section{Statistical Analysis:}

Data were represented as means \pm standard deviation (SD). Differences were statistically analyzed by one-way analysis of variance (ANOVA test) using SPSS 16software package and considered significant at $P$ values $<0.05$ according to Armitage and Berry (1987).

\section{Results and Discussions}

\section{Chemical composition:}

The chemical composition (on dry weight basis per $100 \mathrm{~g}$ ) of golden berry is presented in Table (1), It is noticed from the data that fat, protein, carbohydrate, fiber, and moisture representing 3.12, 10.59, 56.53, 9.2, and $19.28 \%$ respectively, giving energy representing $297 \mathrm{kcal}$. The chemical composition of sweet cherry, as fat, protein, carbohydrate, fiber, and moisture showed 0.58, 4.62, $73.53,2.3$, and $18.3 \%$ respectively, giving energy representing $318 \mathrm{kcal}$. Also Table (1) showed the content of vit. $C$, vit. $E$ and $\beta$ Carotene.

Table (1)

Chemical composition of Golden berry and sweet cherry (per $100 \mathrm{~g}$ )

\begin{tabular}{c|c|c|c|c|c|c}
\hline $\begin{array}{c}\text { Nutritional } \\
\text { component }\end{array}$ & Fat \% & Protein \% & Carbohydrate\% & Moisture \% & Energy kcal & Ash \% \\
\hline Golden berry & 3.12 & 10.59 & 56.53 & 19.28 & 296.56 & 10.48 \\
\hline Sweet cherry & 0.58 & 4.62 & 73.53 & 18.3 & 317.82 & 2.97 \\
\hline Nutritional & Fiber & Sodium (Na) & Potassium,(K) & Vit. E & Vit.C & $\beta$ Carotene \\
component & $\%$ & $\mathrm{mg}$ & $\mathrm{mg}$ & $\mathrm{mg}$ & $\mathrm{Mg}$ \\
\hline Golden berry & 9.2 & 78 & 678 & 0.78 & 7.8 & 2.65 \\
\hline Sweet cherry & 2.3 & 12.4 & 343 & 1.34 & 17.4 & 1.69 \\
\hline
\end{tabular}

Golden berries are fruits known for their popular organoleptic properties (flavor, odor and colour), nutritional value (vitamins $\mathrm{B}$ and $\mathrm{C}$ ) and health benefits (Puente et al. 2011).Physalisperuviana contains health-promoting compounds such as vitamin C (Bravo et al. 2015; Olivares-Tenorio et al., 2016) carotenoids and flavonoids have antioxidant activity. Physalis fruit contains phenols, flavonoids, tannins, alkaloids, anthocyanins and carotenoids. Physalis have high nutritional value because of their high contents of vitamins, minerals and antioxidants. These plants have also potential medicinal properties like antibacterial, anti-inflammatory, and antioxidant properties (Yen et al. 2010). $\beta$-carotene is very important in the prevention of certain human disseases. The reason that carotenoids related to the antioxidant activity that deactivates free radicals generated in tissues (Castro et al., 2015). Hassanien (2011) reported that goose berry is a good source of provitamin A, minerals, vitamin C, and vitamin B complexes, high level of ascorbic acid in the fruit of $P$. peruviana $\mathrm{L}$. plays an important role in human nutrition, including growth and maintenance of tissues, the production of neurotransmitters, hormones and immune system responses.

Carbohydrates are the most abundant macronutrients found in cherries (Bastos et al., 2015). Although differences can be observed among cultivars, in general terms fruits exhibit moderate amounts of carbohydrates between 12.2 and $17.0 \mathrm{~g}$ per $100 \mathrm{~g}$ edible portion for sweet cherry, while sour cherry fruit has an average value of $12.2 \mathrm{~g}$ per $100 \mathrm{~g}$ edible portion (USDA ARS, 2016). In 


\section{Egypt. J. of Nutrition and Health Vol. 14 No. 2July (2019)}

addition, cherry fruit is a moderate source of dietary fiber, accounting for $1.3-2.1 \mathrm{~g}$ per $100 \mathrm{~g}$ edible portion (McCune et al., 2011). For sweet cherries, the protein content is between 0.8 and $1.4 \mathrm{~g}$ per $100 \mathrm{~g}$ edible portion (Serradilla et al., 2016).However, for sour cherries, the protein content is below $1.0 \mathrm{~g}$ per $100 \mathrm{~g}$ edible portion, In general, the fat content of sweet and sour cherries is low and below $1.0 \mathrm{~g}$ per $100 \mathrm{~g}$ edible portion, particularly saturated fat as cherries are a cholesterol-free fruit (Ferretti et al., 2010).

Cherries were reported to have a moderate amount of potassium. In addition, patients with chronic kidney disease will have to pay attention to the potassium content of these extracts." we observed a decrease in serum sodium ( $\mathrm{Na}+$ ) in glycerol treated rats Najafzadeh et al., (2011)

\section{Biological evaluation of investigated rats:}

Feed intake (FI), body weight gain \% (BWG) and Feed efficiency ratio (FER) of injected rats by glycerol are shown in Table (2). The data revealed that Fl of injected rats was declined significantly than those of the negative control rats. At 10\% golden berry and sweet cherry there were significant increase in $\mathrm{Fl}$ compared with positive control. BWG showed the lowest significant value at the positive control group when compared to normal rats, the best result was in golden berry and sweet cherry $(10 \%)$.FER recorded the lowest significant value at positive control. The highest value was in golden berry and sweet cherry $(10 \%)$.

Table (2)

The effect of supplementing golden berry and sweet cherry on feed intake, body weight gained(BWG)and feed efficiency ratio (FER) of the experimental rats

\begin{tabular}{c|c|c|c}
\hline Groups & FI (g)/day & BWG $(\mathrm{g})$ & FER \\
\hline Negative control & $16.86 \pm 0.42^{\mathrm{a}}$ & $25.49 \pm 1.9^{\mathrm{c}}$ & $0.07 \pm 0.01^{\mathrm{c}}$ \\
\hline Positive control & $12.47 \pm 0.63^{\mathrm{c}}$ & $22.8 \pm 4.6^{\mathrm{d}}$ & $0.05 \pm 0.02^{\mathrm{d}}$ \\
\hline Golden berry (5\%) & $15.66 \pm 1.02^{\mathrm{b}}$ & $25.7 \pm 1.1^{\mathrm{c}}$ & $0.07 \pm 0.01^{\mathrm{c}}$ \\
\hline Golden berry (10\%) & $17.37 \pm 1.01^{\mathrm{a}}$ & $28.5 \pm 2.3^{\mathrm{b}}$ & $0.09 \pm 0.02^{\mathrm{b}}$ \\
\hline Sweet cherry (5\%) & $15.51 \pm 0.58^{\mathrm{b}}$ & $26.2 \pm 5.1^{\mathrm{c}}$ & $0.08 \pm 0.02^{\mathrm{c}}$ \\
\hline Sweet cherry (10\%) & $17.26 \pm 0.59^{\mathrm{a}}$ & $31.57 \pm 2.6^{\mathrm{a}}$ & $0.11 \pm 0.01^{\mathrm{a}}$ \\
\hline
\end{tabular}

Means with dissimilar letters (a, b, c, d, etc.) in the same column differ significantly at $p \leq 0.05$ by Duncan test, while those with similar letter completely or partially are non-significantly different

Ahmed, (2014) evaluated the renoprotective effect of physalis peruviana L. extract (PPE) on acute renal injury in rats. The author showed inhibition of the body weight loss. Hassanien (2011) reported that gooseberry is a good source of provitamin A, minerals, vitamin $C$, and vitamin $B$ complexes, high level of ascorbic acid in the fruit of $P$. peruviana $L$. plays an important role in human nutrition, including growth and maintenance of tissues, the production of neurotransmitters, hormones and immune system responses.

Sujana et al., (2016)reported that sweet cherry is rich source of organic acids. These organic acids contain an emulsifying effect on the fat deposits. The authors mentioned that it was good for obesity people.Girelli et al., (2016) showed that sweet cherries were a source of dietary phenolic compounds including phenolic acids (hydroxyl cinnamic acids) and flavonoids (anthocyanins, flavan-3ols and flavonols), which are known for their health benefits and important role of sweet cherry extracts, appropriately formulated as nutraceutical food, as prevention and good for obese children. 


\section{Ola Ibrahim El-Desoky Ali, et al}

Sweet cherry is often recommended to help regulate metabolism, and to support weight loss. Because of their ability to help the body flush out wastes and toxins, sweet cherry is believed to help the body eliminate fat and cellulite and to help the skin retain / regain its shape and elasticity throughout the weight loss process (Girelli et al., 2016).

\section{Relative organs weight:}

The relative weight of kidney, liver and heart to body weight in rats' injected with glycerol after being fed on golden berry and sweet cherry are shown in Table (3). Kidney, liver and heart weight were significantly increased at $(\mathrm{p}<0.05)$ in the positive control group when compared to normal rats' group.However, there is significant improvement of all golden berry and sweet cherry treatments compared with the positive control group.

Table (3)

The effect of supplementing golden berry and sweet cherry on organs relative weight of the experimental rats

\begin{tabular}{c|c|c|c}
\hline Groups & Kidney \% & Liver \% & Heart \% \\
\hline Negative control & $0.70 \pm 1.6^{\mathrm{d}}$ & $2.82 \pm 0.18^{\mathrm{b}}$ & $0.31 \pm 0.06^{\mathrm{e}}$ \\
\hline Positive control & $0.93 \pm 0.20^{\mathrm{a}}$ & $3.15 \pm 0.6^{\mathrm{a}}$ & $0.41 \pm 0.07^{\mathrm{a}}$ \\
\hline Golden berry (5\%) & $0.75 \pm 0.06^{\mathrm{d}}$ & $2.59 \pm 0.25^{\mathrm{c}}$ & $0.33 \pm 0.03^{\mathrm{e}}$ \\
\hline Golden berry (10\%) & $0.84 \pm 0.06^{\mathrm{c}}$ & $2.66 \pm 0.26^{\mathrm{c}}$ & $0.36 \pm 0.06^{\mathrm{d}}$ \\
\hline Sweet cherry (5\%) & $0.84 \pm .15^{\mathrm{c}}$ & $2.78 \pm 0.26^{\mathrm{b}}$ & $0.40 \pm 0.08^{\mathrm{b}}$ \\
\hline Sweet cherry (10\%) & $0.87 \pm .15^{\mathrm{b}}$ & $3.21 \pm 0.41^{\mathrm{a}}$ & $0.39 \pm 0.09^{\mathrm{c}}$ \\
\hline
\end{tabular}

Means with dissimilar letters ( $a, b, c, d$, etc.) in the same column differ significantly at $p \leq 0.05$ by

Duncan test, while those with similar letter completely or partially are non-significantly different

According to Al-Basher, et al., (2019)glycerol injection resulted in histopathological changes such as renal tubular injury due to rat's tubular myoglobin deposition. Glycerol-injected rats showed a significant increase in the kidney relative weight

Castro et al., (2015) reported that an extract from the husk of golden berries reduced inflammation in mice. Additionally, mice treated with this extract had lower levels of inflammatory markers in their tissues, Golden berries are rich in antioxidants, also the intake of vitamin E, A and the increase the antioxidant protect the organs; heart, liver, lungs, spleen, and kidneys in rats. (Seymour et al., 2008)showed that sweet cherry diet was associated with a non-significant increase in heart, and liver weight relative to total body weight as there was a significant increase in kidney weight. Sweet cherry have proven helpful in the treatment of kidney issues, gout and rheumatism, as well as to help strengthen the nerves by exerting an overall calming effect.

\section{Biochemical analysis: \\ Kidney function:}

The data in Table (4) show the effect of supplemented diets with golden berry and sweet cherry on kidney function; uric acid, urea, and creatinine. Glycerol injection, not only affect the kidney weight but also the kidney functions as implied by the increase of plasma creatinine, urea, and uric acid in the positive control group which is significantly higher compared to the normal control group. Sweet cherry (10\%)and golden berry (10\%) groups had significantly decreased the plasma levels of uric acid, urea and creatinine. The best results of plasma creatinine levels of treated groups were found in the group put on sweet cherry $(10 \%)$. 
Egypt. J. of Nutrition and Health Vol. 14 No. 2July (2019)

Table (4)

The effect of supplementing golden berry and sweet cherry on kidney function of the experimental rats

\begin{tabular}{|c|c|c|c|}
\hline $\begin{array}{ll}\text { Groups } & \text { Parameters }\end{array}$ & Uric acid $\left(\mathrm{mg} \mathrm{dl}^{-1}\right)$ & Urea (mg dl-1) & Creatinine $\left(\mathrm{mg} \mathrm{dl}^{-1}\right)$ \\
\hline Negative control & $2.38 \pm 0.24^{\dagger}$ & $33.1 \pm 2.3^{\mathrm{d}}$ & $0.43 \pm 0.05^{\mathrm{d}}$ \\
\hline Positive control & $6.31 \pm 0.13^{a}$ & $61.7 \pm 1.03^{\mathrm{a}}$ & $1.23 \pm 0.08^{\mathrm{a}}$ \\
\hline Golden berry (5\%) & $3.91 \pm 0.19^{c}$ & $44.0 \pm 3.8^{b}$ & $0.67 \pm 0.11^{\mathrm{bc}}$ \\
\hline Golden berry (10\%) & $3.3 \pm 0.26^{b}$ & $34.3 \pm 5.5^{\mathrm{d}}$ & $0.60 \pm 0.14^{\mathrm{C}}$ \\
\hline Sweet cherry (5\%) & $4.3 \pm 0.41^{\mathrm{D}}$ & $39.5 \pm 4.6^{c}$ & $0.73 \pm 0.05^{b}$ \\
\hline Sweet cherry (10\%) & $2.7 \pm 0.20^{\mathrm{e}}$ & $33.6 \pm 2.3^{d}$ & $0.43 \pm 0.10^{\mathrm{d}}$ \\
\hline
\end{tabular}

Means with different letters ( $a, b, c, d$, etc.) in the same column differ significantly at $p \leq 0.05$ by Duncan test, while those with similar letter completely or partially are non-significantly different

Mousleh et al., (2018) showed that serum urea and creatinine levels were increased $(\mathrm{P}<0.001)$ in glycerol-injected rats. Taj et al., (2014)reported that animal fed with various preparations of physalis peruviana showed significant lowering effect $(p<0.05)$ in the elevated levels of serum markers like creatinine and urea indicating the protection against kidney cell damage. The water extract of physalis peruviana, phytosterols and tocopherols used as a nutritional complement which showed highest activity may be due to its antioxidant and anti-inflammatory effects. Braunlich et al., (2013) showed the effect of cherries on the renal tubular transport of urate. "While increased urate excretion may have contributed to a decreased risk of gout, another possibility is that sweet cherry has an anti-inflammatory effect that decreases gout attacks". Anthocyanins inhibited the activity of Xanthine oxidase, the enzyme involved in uric acid synthesis, in vitro and also decreased serum uric acid concentration in hyperuricemic mice (Decendit et al., 2013).

\section{Serum proteins:}

The data in Table (5) show the effect of supplemented diets with golden berry and sweet cherry on Serum proteins; (total protein, albumin and globulin). It is noticed that glycerol injection led to significant decrease in plasma total protein, albumin, globulin and $A / G$ ratio of the positive control group compared to the normal control group. Sweet cherry $(10 \%)$ and golden berry (10\%) groups increased significantly the plasma levels of total protein, albumin, globulin and A/G ratio. The best results in the level of total protein and other parameter were found in treated groups with $10 \%$ of each cherry and golden berry.

Table (5)

The effect of supplementing golden berry and sweet cherry on serum proteins of the experimental rats

\begin{tabular}{|c|c|c|c|c|}
\hline $\begin{array}{l}\text { Parameters } \\
\text { Groups }\end{array}$ & Total protein $\left(\mathrm{g} \mathrm{dl}^{-1}\right)$ & $\operatorname{Albumin}\left(\mathrm{g} \mathrm{dl}^{-1}\right)$ & Globulin(g dl-1) & A/G Ratio \\
\hline Negative control & $7.41 \pm 0.98^{\mathrm{a}}$ & $4.4 \pm 0.19^{a}$ & $3.4 \pm 0.15^{\mathrm{a}}$ & $1.4 \pm 0.12^{\mathrm{a}}$ \\
\hline Positive control & $6.2 \pm 0.08^{e}$ & $3.2 \pm 0.11^{d}$ & $2.9 \pm 0.12^{b}$ & $1.09 \pm 0.08^{d}$ \\
\hline Golden berry (5\%) & $6.4 \pm 0.10^{d}$ & $3.6 \pm 0.10^{c}$ & $2.8 \pm 0.14^{b}$ & $1.23 \pm 0.09^{b c}$ \\
\hline Golden berry (10\%) & $7.3 \pm 0.13^{b}$ & $4.1 \pm 0.05^{b}$ & $3.2 \pm 0.16^{\mathrm{a}}$ & $1.26 \pm 0.07^{b}$ \\
\hline Sweet cherry (5\%) & $6.7 \pm 0.18^{c}$ & $3.5 \pm 0.10^{c}$ & $3.18 \pm 0.24^{a}$ & $1.13 \pm 0.11^{\mathrm{c}}$ \\
\hline Sweet cherry $(10 \%)$ & $7.4 \pm 0.13^{\mathrm{ab}}$ & $4.2 \pm 0.05^{\mathrm{b}}$ & $3.2 \pm 0.17^{a}$ & $1.29 \pm 0.08^{b}$ \\
\hline
\end{tabular}

Means with different letters (a, b, c, d, etc.) in the same column differ significantly at $p \leq 0.05$ by Duncan test, while those with similar letter completely or partially are non-significantly different 


\section{Ola Ibrahim El-Desoky Ali, et al}

This matches with Ahmed, (2014) who reported significant improvement in serum proteins of rats given Physalisperuviana L. compared to their corresponding positive control. The reduction of serum protein level in rats (positive control) might be due to loss in urine due to kidney dysfunction or loss of muscle protein.Serum hypo-albuminemia is related to protein energy wasting and strongly associated with increased morbidity and attenuation of exercise-induced muscle damage. Consuming sweet cherry make recovery of muscle damage because of their phenolic compounds, as well as their antioxidant, anti-inflammatory and health-promoting properties (Leonardo, et al., 2015).

Tomás-Barberán and Espín, (2001)reported that sweet cherry polyphenols include phenolic acids (hydroxycinnamic and hydroxybenzoic acids) and flavonoids (anthocyanins, flavonols and flavan3-ols). (Viljevac et al., 2012).

\section{Serum electrolytes sodium ( $\mathrm{Na}+)$ and Potassium (K+)}

The data in Table (6) show the effect of supplemented diets with golden berry and sweet cherry on serum electrolytes sodium and Potassium. It showes that glycerol injection caused significant decrease in plasma sodium and Potassium of the positive control group compared to the normal control group. Both golden berry and sweet cherry groups $(10 \%)$ had significant increase of electrolytes; sodium and potassium in plasma.

Table (6)

The effect of supplementing golden berry and sweet cherry on serum electrolytes sodium ( $\mathrm{Na}+)$ and potassium $(\mathrm{K}+)$ of the experimental rats

\begin{tabular}{l|l|l}
\hline Groups & \multicolumn{1}{|c|}{$\mathrm{Na}\left(\mathrm{mg} \mathrm{dL}^{-1}\right)$} & \multicolumn{1}{c}{$\mathrm{K}\left(\mathrm{mg} \mathrm{dL}^{-1}\right)$} \\
\hline Negative control & \multicolumn{1}{c}{ Parameters } & $5.4 \pm 0.6^{\mathrm{a}}$ \\
\hline Positive control & $151.3 \pm 1.3^{\mathrm{a}}$ & $3.5 \pm 0.2^{\mathrm{de}}$ \\
\hline Golden berry (5\%) & $141.8 \pm 1.4^{\mathrm{e}}$ & $4.2 \pm 0.1^{\mathrm{c}}$ \\
\hline Golden berry (10\%) & $145.3 \pm 1.8^{\mathrm{c}}$ & $4.8 \pm 0.08^{\mathrm{b}}$ \\
\hline Sweet cherry (5\%) & $149.1 \pm 1.9^{\mathrm{b}}$ & $4.0 \pm 0.08^{\mathrm{d}}$ \\
\hline Sweet cherry (10\%) & $143.6 \pm 1.8^{\mathrm{d}}$ & $4.9 \pm 0.2^{\mathrm{b}}$ \\
\hline
\end{tabular}

Means with different letters ( $a, b, c, d$, etc.) in the same column differ significantly at $p \leq 0.05$ by Duncan test, while those with similar letter completely or partially are non-significantly different

Park et al., (2012) showed that glycerol induced renal failure in rats was associated with significant increase in fractional excretion of sodium.Our findings are in agreement with earlier investigators who reported a significant decrease in serum $\mathrm{Na}+$ in glycerol injected rat.

Sweet cherries provides $10 \%$ of potassium, a mineral that is essential for keeping healthy heart. It is needed to maintain a regular heartbeat and helps to remove excess sodium from the body, regulating blood pressure. Higher intake of potassium is associated with reduced risk of heart disease and stroke What's more, cherries are rich in powerful polyphenol antioxidants, including anthocyanins, flavonols and catechins which may help keep healthy heart by protecting against cellular damage and reducing inflammation Kaya et al., (2013).

Najafzadeh et al., (2011)reported that patients with kidney disease, were frequently concerned with potassium intake. The level of potassium $\left(\mathrm{K}_{+}\right)$was also shown to be elevated significantly, in the affected group (glycerol alone), this was as a result of the damage to the proximal convulated tubule (Crook, 2012). This agrees with the work of (Lehnhardt and Kemper, 2011) who 


\section{Egypt. J. of Nutrition and Health Vol. 14 No. 2July (2019)}

reported that acute renal insufficiency leads to increased serum potassium, however, these levels were shown to be decreased significantly, in the positive control group as a result of the antioxidant and antiinflammatory property of vitamin $\mathrm{C}$ to ameliorate the damage to the tubules.

In this context; Puente et al., (2011) found that the antioxidant activity associated with physalis peruvianaL. is due to the high levels of polyphenols. The study estimated good amounts of total phenolic and flavonoid compounds in physalis peruviana $L$. extract. In this respect, significant amounts of phenolic and flavonoid compounds in physalis peruviana L. extracts were reported (Wu et al., 2009), while others considered the fruit of Physalis peruviana $L$. is a source of phenolic compounds in food (Ramadan, 2011 and Puente et al.,2011).

\section{Liver enzymes:}

Liver enzymes expressed as SGOT and SGPT ( $\left.\mathrm{U} \mathrm{L}^{-1}\right)$ of all groups are shown in Table (7). The mean values of SGPT enzyme in the control positive group injected with glycerol were significantly higher at $(\mathrm{p}<0.05)$ compared to normal rats group. The best results were recorded in golden berry $(10 \%)$ and sweet cherry (10\%), where the SGPT is significantly lower than the positive control. Treated groups with $10 \%$ golden berry and $10 \%$ sweet cherry had a significant decrease in serum levels. Hence, treated groups with sweet cherry and golden berry revealed the greatest decline in enzyme levels in the serum as compared with the positive control group.

Table (7)

The effect of supplementing golden berry and sweet cherry on plasma liver enzymes of the experimental rats

\begin{tabular}{|c|c|c|}
\hline Groups $\quad$ Parameters & $\operatorname{SGPT}\left(\mathrm{U} \mathrm{L}^{-1}\right)$ & SGOT ( U L L $)$ \\
\hline Negative control & $24.0 \pm 1.41^{\dagger}$ & $42.5 \pm 1.87^{d}$ \\
\hline Positive control & $65.7 \pm 1.03^{a}$ & $85.0 \pm 3.22^{\mathrm{a}}$ \\
\hline Golden berry (5\%) & $37.7 \pm 0.81^{b}$ & $53.1 \pm 2.22^{b}$ \\
\hline Golden berry (10\%) & $26.7 \pm 1.63^{\mathrm{e}}$ & $47.6 \pm 1.50^{\mathrm{C}}$ \\
\hline Sweet cherry (5\%) & $33.7 \pm 2.65^{c}$ & $47.5 \pm 1.51^{\mathrm{C}}$ \\
\hline Sweet cherry (10\%) & $28.8 \pm 2.1^{d}$ & $45.8 \pm 1.7^{c}$ \\
\hline
\end{tabular}

Means with dissimilar letters (a, b, c, d, etc.) in the same column differ significantly at $p \leq 0.05$ by Duncan test, while those with similar letter completely or partially are non-significantly different

Taj et al., (2014)showed the anti-hepatotoxic effect of physalis peruviana in the whole ripe fruit. Animals treated/fed with various preparations of physalis peruviana showed significant lowering effect $(p<0.05)$ in the elevated levels of serum markers like SPGT and SGOT indicating the protection against hepatic cell damage. The possible mechanism of the physalis peruviana as hepatoprotective element may be due to its antioxidant effect. Also, the same author reported that different compounds: 28- hydroxywithanolide, withanolides, phygrine, kaempferol, and quercitin di- and tri-glycosides are present in physalis peruviana. These compounds have a strong antioxidant property and prevent oxidative damage to liver microsomes and hepatocytes. It has been reported that physalis peruviana contains phytochemicals, flavonoids, saponins and phenols. Flavonoids are powerful antioxidants against free radicals and are described as free-radical scavengers. The antioxidant property is claimed to be one of the mechanisms of hepatoprotective impact. 


\section{Antioxidant enzyme marker:}

Table (8) shows the antioxidant activities of plasma superoxide dismutase (SOD) in all groups of rats. It is clear that, due to glycerol injection, the activities of plasma SOD significantly declined; this loss of antioxidant enzymes as a result of liver disorders. SOD enzyme of 5, $10 \%$ golden berry and sweet cherry group's recorded significant change compared to positive control group.

Table (8)

The effect of supplementing golden berry and sweet cherry on plasma superoxide dismutase(SOD), and malondialdehyd (MDA) ofliver tissue of the experimental rats

\begin{tabular}{l|c|c}
\hline Groups & Marameters & SOD $\left(\mathrm{U} \mathrm{ml}^{-1}\right)$ \\
\hline Negative control & $14.7 \pm 1.3^{\mathrm{d}}$ & $152.1 \pm 1.3^{\mathrm{a}}$ \\
\hline Positive control & $29.5 \pm 0.8^{\mathrm{a}}$ & $116.1 \pm 1.7^{\mathrm{f}}$ \\
\hline Golden berry (5\%) & $26.2 \pm 0.7^{\mathrm{b}}$ & $126.0 \pm 1.5^{\mathrm{e}}$ \\
\hline Golden berry (10\%) & $19.9 \pm 0.6^{\mathrm{c}}$ & $143.6 \pm 1.2^{\mathrm{c}}$ \\
\hline Sweet cherry (5\%) & $23.4 \pm 2.3^{\mathrm{b}}$ & $129.5 \pm 1.4^{\mathrm{d}}$ \\
\hline Sweet cherry (10\%) & $16.8 \pm 1.6^{\mathrm{c}}$ & $147.6 \pm 1.8^{\mathrm{b}}$ \\
\hline
\end{tabular}

Means with different letters (a, b, c, d, etc.) in the same column differ significantly at $p \leq 0.05$ by Duncan test, while those with similar letter completely or partially are non-significantly different

Other studies have demonstrated that timely prophylactic and/or early therapeutic interventions (either pre- or coadministration) ameliorated glycerol-induced acute kidney injury (Homsi et al., 2010; Wang et al., 2011). The mechanism of generation of oxidative stress was through the release of iron from heme group of myoglobin. Iron induces the generation of superoxides and high activity oxides such as hydrogen peroxide and oxygen molecules that increase oxidative stress and provoke lipid peroxidation and cellular death .Ahmed, (2014) reported that physalis peruviana $L$. resulted a significant increments in SOD as compared with other groups. Cherry compounds have been shown to increase the activity of the body's antioxidant enzyme, superoxide dismutase (SOD). Researchers have stated that sweet cherry "have the highest antioxidant and anti-inflammatory content of any food." Also, sweet cherry compounds increase the activity of superoxide dismutase (SOD), which is the key of antioxidant enzyme. (Sari et al., 2009)

\section{Lipid peroxidation assay of liver tissue:}

Data in table (8) demonstrated the protective effect of sweet cherry and golden berry on malondialdehyde(MDA) as lipid peroxidation assay of liver tissue. There was a significant increase in MAD level in positive control compared to the negative control. Treated groups with sweet cherry and golden berry $10 \%$ had a significant decrease in MAD level.

Cherry owe its potency in part to high anthocyanin content, their real secret is their extremely broad range of anthocyanins. As a result, sweet cherry synergistically target a remarkably wide spectrum of oxidation- and inflammation-induced diseases. It is worth noting that sweet cherry mostly reducing effect on elevated MDA concentration in hyperuricemic rats rather than on the normal MDA concentration. Studies have identified the active antioxidants within sweet cherry as eight polyphenolic compounds, including anthocyanins, chlorogenic acid, gallic acid, $p$-coumaric acid and quercetin (Chaovanalikit and Wrolstad, 2004).Anthocyanins from cherries could significantly decrease MDA in serum and increase activity of SOD in serum on day 28 after the injection. (Suzuki et al., 


\section{Egypt. J. of Nutrition and Health Vol. 14 No. 2July (2019)}

2004).Furthermore, (Singhet al., 2006)concluded that renoprotective effect of polyphenols can be ascribed to their potent ROS scavenging and metal chelating properties. In the light of this, it was found that quercetin is the main polyphenols in physalisperuviana L., followed by myricetin and kaempferol. Quercetin, for example, has various biological activities such as antioxidant and anti-inflammatory functions (Sadowska-Woda et al., 2010)

\section{Conclusion and recommendation:}

The results from this study focus on the effect of golden berry and sweet cherry on acute renal failure in rats induced by glycerol. As glycerol injection caused renal tubular injury and renal tubular myoglobin deposition together with disturbed liver metabolism. Thus, the study proved that using golden berry and sweet cherry in diets of the rats protected the internal organs functions from damage by glycerol. The study recommends its trial on patients with disturbed liver and kidney function before its generalization.

\section{References}

Ahmed L. A. (2014).

Reno-protective Effect of Egyptian Cape Gooseberry Fruit (PhysalisPerviana.L) against Acute Renal Injury in Rats. The scientific world Journal volume 2014 Articale ID273870, 7page.

Al-Basher G; Alfarraj S; Alarifi S; Alkhtani1 S; Almeer R; Alsultan N; Alharthi M; Alotibi N; Aldbass A; Ahmed E; and Abdel Moneim D. (2019).

Nephroprotective Role of Beta vulgaris L. Root Extract against Chlorpyrifos-Induced Renal Injury in Rats.Journal of Evidence-Based Complementary and Alternative Medicine Volume 2019 |Article ID 3595761 | 9 pages | https://doi.org/10.1155/2019/3595761

Armitage , P. and Berry, G. (1987):

Statistical Methods in Medical Research . Blackwell , Oxford, UK, 93-213.

A.O.A.C., (2000).

Official Methods of Analysis, $17 \mathrm{Ed}$.. Association of Official Analytic Chemists International. Arlington, Virginia, USA.

Akina, N. Daisuke, Y. Sayaka, N. Hiroko, A. Yumi, H. Hirotaro, I. (2016).

Evaluations of lipid peroxidation and inflammation in short-term glycerol-induced acute kidney injury in rats. Journal Citation Reports Clinical and experimental pharmacology and physiology 43, (11): 1080-1086

Anonymous, (1966).

Methods of Vitamin Assay. Interscience Publishers, New York, USA, pp: 237-307.

Bastos, C., Barros, L., Dueñas, M., Calhelha, R.C., Queiroz, M.J.R.C., Santos-Buelga, C. and Ferreira, I.C.F.R. (2015):

Chemical characterisation and bioactive properties of Prunusavium L.: the widely studied fruits and the unexplored stems. Journal of food Chemistry Apr 15;173:1045-53. 
Braunlich, M., Slimestad, R., Wangensteen, H., Brede, C., Malterud, K.E., Barsett, H. (2013). Extracts, anthocyanins and procyanidins from Aroniamelanocarpa as radical scavengers and enzyme inhibitors. Nutrients, 5, 663-678.

Bravo, K., Sepulveda-Ortega, S., Lara-Guzman, O., Navas-Arboleda, A. A., Osorio, E (2015). Influence of cultivar and ripening time on bioactive compounds and antioxidant properties in Cape gooseberry (PhysalisperuvianaL.). Journal of the Science of Food and Agriculture. 95 (7): 1562-9.

Castro, J. Ocampo, Y. Franco, L. (2015).

Cape gooseberry [Physalisperuviana L.] Calyces Ameliorate TNBS Acid-induced Colitis in Rats Journal ofCrohns Colitis. 9(11):1004-15. doi: 10.1093/ecco-jcc/jjv132. Epub 2015 Jul 27

Chaney, S.G., (2006).

Principles of Nutrition I: Macronutrients. In: Devlin, T.M. (ed.), Textbook of Biochemistry, with Clinical Correlation, 6th ed. John Wiley and sons, New York, pp: 1071-1090.

Chang J. C., Lin, C. C. and Wu. S. J., (2008).

Anti-oxidative and hepato-protective effects of Physalisperuviana extract against acetaminophen-induced liver injury in rats. Pharmaceutical Biology. 2008;46 (10-11):724731.

Chaovanalikit, A., Wrolstad, R.E. (2004).

Total anthocyanins and total phenolics of fresh and processed cherries and their antioxidant properties. J. Food Sci., 69, FST67-FST72.

Chapman, D.G., Castilla, R. and Campbell, J.A. (1959).

Evaluation of protein in food. I. A method for the determination of protein efficiency ratio. Can.

J. Biochem. Physiol., 37:679-689.

Chary, T.M. and Sharma, H. (2004).

Practical Biochemistry For Medical And Dental Students. Jay pee Brothers Medical Publishers (P) LTD, New Delhi.

Crook A.C. (2012).

The Kidneys, Clinical Biochemistry and Metabolic Medicine.8thEdn, Joanna K., Jenny W.,(eds) Horder Arnold Publisher, London.2012, 45-46.

Decendit, A., Mamani-Matsuda, M., Aumont, V., Waffo-Teguo, P., Moynet, D., Boniface, K., Richard, E., Krisa, S., Rambert, J., Merillon, J.M., (2013).

Malvidin-3-O-beta glucoside, major grape anthocyanin, inhibits human macrophage-derived inflammatory mediators and decreases clinical scores in arthritic rats. Biochem. Pharmacol. 86:1461-1467

Drupt, F. (1974).

Colorimetric method for determination of albumin. Pharm. Biol., 9: 777-779. 
Egypt. J. of Nutrition and Health Vol. 14 No. 2July (2019)

Drury, R .A. and Wallington , E.A. (1980).

Carton's histological technique. 5th Ed., Oxford University. UK.

Faulkner, N.R. and King, J.W. (1976).

Fundamental of clinical chemistry. 2nd Ed. Tietz Editor. Saunders Philadelhia, 994-998.

Ferretti G., Bacchetti T., Belleggia A., Neri D. (2010).

Cherry antioxidants: From farm to table. Molecules. ;15:6993-7005.

Fossati , P., Prencipe , L. and Berti , G. (1980).

Enzymatic colorimetric method for determination of uric acid in serum. Clin. Chem., 26 (2) : 227-273.

Girelli CR, De Pascali SA, Del Coco L, Fanizzi FP.(2016).

Metabolic profile comparison of fruit juice from certified sweet cherry trees (Prunusavium L.) of Ferrovia and Giorgia cultivars: a preliminary study. Food Res Int. 90:281-7. 10.1016/j.foodres.2016.11.014

Hassanien, M. F. R., ( 2011 ).

Physalisperuviana: A Rich Source of Bioactive Phytochemicals for Functional Foods and PharmaceuticalsFood Reviews International27 (3), 259-27.

Henry, T.J. (1974).

Clinical Chemistry Principles and Techniques. 2th ed. Harper and Row Publishers; New York

Homsi E, De Brito SM, Janino P. (2010).

Silymarin exacerbates p53-mediated tubular apoptosis in glycerol-induced acute kidney injury in rats. Ren Fail 32:623-632

Jacob, R.A.; Spinozzi, G.M.; Simon, V.A.; Kelley, D.S.; Prior, R.L.; Hess-Pierce, B.; Kader, A.A. (2003).

Consumption of cherries lowers plasma urate in healthy women. J. Nutr., 133, 1826-1829.

Jerome, B.; Elyett, G.; Edmond, R.; Andrzej, M. and Yves ,R.(2002):

Substituting honey for refined $\mathrm{CHO}$ protects rats from hypertriglyceridemic and prooxidative effects of fructose". J. Nutr.- France, P. 55-65.

Kakkar, P.; Das, B. and Viswanathan, P.N. (1984).

A modified spectrophotometric assay of superoxide dismutase. Indian J. Biochem. Biophys., 21: $130-132$.

Kaya, O. Aydogdu, N. Tastekin, E. Karadag, CH. Unduz, OG. Sut, N. ( 2013).

Effects of losartan on glycerol-induced myoglobinuric acute renal failure in rats. KafkasUniv Vet FakDerg.; 19(2):253-8.

Lehnhardt A., and Kemper J.M. (2011).

Pathogenesis, Diagnosis, and management of hyperkalemia, Pediatric Nephrology. 26(3), 377-384. 
Ola Ibrahim El-Desoky Ali, et al

Leonardo C. R., Oliveira Assumpcao C., Prestes J., Denadai B. (2015).

Consumption of cherries as a strategy to attenuate exercise-induced muscle damage and inflammation in humans. Nutr. Hosp. ;32:1885-1893.

Lindsey, W.L. and Norwell, M.A. (1969).

A new DPTATEA soil test for zinc and iron. Agronomy Abstracts, 61: 84.

McCune L.M., Kubota C., Stendell-Hollis N.R., Thomson C.A. (2011).

Cherries and health: A review. Crit. Rev. Food Sci. Nutr. ; 51:1-12.

Mousleh R., Al Laham S. and Al-Manadili A., (2018).

The Preventive Role of Pioglitazone in Glycerol-Induced Acute Kidney Injury in Rats during Two Different Treatment Periods Iranian Journal of Medical Sciences. 2018 Mar; 43(2): 184194

Najafzadeh H, Razijalali M, Morovvati H, Navvabi L. (2011).

Evaluation the effect of cimetidine, estradiol and vitamin $E$ on myoglobinuric renal toxicity in rats. Am Eurasian J. Toxicol Sci.; 3 (3):177-83.

Okhawa, H.; Ohishi, N. and Yagi, K. (1979).

Assay for lipid peroxidation in animal tissues by thiobarbituric acid reaction. Annals of Biochemistry. 95:351-358.

Olivares-Tenorio, M.L.; Dekker, M.; Verkerk, R.; Van Boekel, M.A.J.S. (2016):

Health-promoting compounds in cape gooseberry (Physalisperuviana L.): review from a supply chain perspective. Trends in Food Science and Technology, v.57, p.83- 92, 2016. DOI: 10.1016/j.tifs.2016.09.009.

Park, CH. Tanaka, T. Cho, EJ. Park, JC. Shibahara, N. Yokozawa, T. (2012).

Glycerol-induced renal damage improved by 7-O-galloyl-D-sedoheptulose treatment through attenuating oxidative stress. Bio. Pharm Bull; 35(1):34-41.

Patton, C. J. and Crouch, S.R. (1977).

Enzymatic colorimetric method for determination of urea in serum. Anal. Chem. , 49 : 464469

Puente LA, Pinto-Muñoz CA, Castro ES, Cortés M. (2011).

Physalisperuviana Linnaeus, the multiple properties of a highly functional fruit: a review. Food Research International. ;44(7):1733-1740.

Ramadan, MF. (2011).

Bioactive phytochemicals, nutritional value, and functional properties of cape gooseberry (Physalisperuviana): an overview. Food Research International. 44(7):1830-1836.

Reitman, S. and Frankel, S. (1957).

A colorimetric method for the determination of serum glutamic oxaloacetic and glutamic pyruvic transaminases. Am. J. Clin. Path. , 28: 56. 
Egypt. J. of Nutrition and Health Vol. 14 No. 2July (2019)

Rodriguez-Amaya, D.B., (1997).

Carotenoids and Food preparation: The retention of Provitamin A Carotenoids in Prepared, Processed and Stored Foods. John Snow, Inc. /OMNI Project, Arlington, VA

Sadowska-Woda I, Popowicz D, Karowicz-Bilińska A. (2010).

Bifenthrin-induced oxidative stress in human erythrocytes in vitro and protective effect of selected flavonols. Toxicology in Vitro. ;24(2):460-464.

Sari, A.; Sobocanec, S.; Balog, T.; Kusić, B.; Sverko, V.; Dragović-Uzelac, V.; Levaj, B.; Cosić, Z.; MacakSafranko, Z.; Marotti, T. (2009).

Improved antioxidant and anti-inflammatory potential in mice consuming sour cherry juice (Prunuscerasus cv. Maraska).Plant Foods Hum. Nutr., 64, 231-237.

Serradilla, M.J., Hernández, A., López-Corrales, M., Ruiz-Moyano, S., Córdoba, M.G. and Martín, A. (2016).

Composition of the cherry (Prunusavium L. and Prunuscerasus L.; Rosaceae). In: Simmonds, M.S.J. and Preedy, V.R. (eds) Nutritional Composition of Fruit Cultivars. Academic Press, London, pp. 127-147.

Seymour M, Andrew A., Singer M., Kirakosyan A, Urcuyo-Llanes D, Peter B. and Steven F. (2008).

Altered Hyperlipidemia, Hepatic Steatosis, and Hepatic Peroxisome Proliferator-Activated Receptors in Rats with Intake of Tart Cherry. Journal of medicinal food J. Med Food 11 (2), 121-132

Singh, D. Kaur, R. Chander, V. Chopra, K. (2006).

Antioxidants in the prevention of renal disease. Journal of Medicinal Food. ;9(4):443-450.

Sonnenwirth, A. and Jaret, L. (1980).

Grad wholes Clinical Laboratory Methods and Diagnosis. Vol. 18th, Ed. Mosby, London 258259

Srivastava, L.M.; Das, N . and Sinha, S.(2002):

Essentials of practical Biochemistry". CBC Publishers and Distributors.

Sujana, K. SaiTejaswini, K. Lakshmi S. (2016).

Cranberry fruit: An update review. International Journal of Herbal Medicine 2016;4 (3): 05-08

Suzuki, H. Sawada, S. Watanabe, K. (2004).

Identification and characterization of a novel anthocyanin malonyltransferase from scarlet sage (Salvia splendens) flowers: an enzyme that is phylogenetically separated from other anthocyanin acyltransferases. Plant J. Jun; 38: 994-1003.

Taj, D., H. Khan , V. Sultana , J. Ara and S. Ehteshamul-Haque, (2014).

Biotechnology and Drug Development Laboratory. Pakistan Journal of Pharmaceutical Sciences, 27(3):491-494. 
Ola Ibrahim El-Desoky Ali, et al

Tomás-Barberán, F.A. and Espín, J.C. (2001).

Phenolic compounds and related enzymes as determinants of quality in fruits and vegetables. Journal of the Science of Food and Agriculture 81, 853-876.

USDA ARS US Department of Agriculture, Agricultural Research Service (2016).

National Nutrient Database for Standard Reference, Release 26. Nutrient Data Laboratory, Available at: https://ndb.nal.usda.gov/ (accessed 2 January 2016).

Viljevac, M., Dugalic, K., Jurkovic, V., Mihaljevic, I., Tomaš, V., Puškar, B., Lepeduš, H., Sudar, R. and Jurković, Z. (2012).

Relation between polyphenols content and skin colour in sour cherry fruits. Journal of Agricultural Science 57, 57-67.

Wang YD, Zhang L, Cai GY, Zhang XG, Lv Y, Hong Q, Shi SZ, Yin Z, Liu XF, Chen XM. (2011). Fasudil ameliorates rhabdomyolysis-induced acute kidney injury via inhibition of apoptosis. Ren Fail 33:811-818

Wu S-J, Chang S-P, Lin D-L, Wang S-S, Hou F-F, Ng L-T. (2009).

Supercritical carbon dioxide extract of Physalisperuviana induced cell cycle arrest and apoptosis in human lung cancer H661 cells. Food and Chemical Toxicology. 47(6):11321138.

Yen, C. Y., Chiu, C. C., Chang, F. R., Chen, J. Y., Hwang, C. C., Hseu,Y. C., Yang, H. L., Lee, A. Y., Tsai, M. T., Guo, Z. L., Cheng, Y.S., Liu, Y. C., Lan, Y. H., Chang, Y. C., Ko, Y. C., Chang, H. W., \& Wu, Y. C. (2010).

4b Hydroxywithanolide E from Physalisperuviana (golden berry) inhibits growth of human lung cancer cells through DNA damage, apoptosis and G2/M arrest. BMCCancer, 10(46). PMid:20167063 PMCid:PMC2830937. 
Egypt. J. of Nutrition and Health Vol. 14 No. 2July (2019)

دراسة التأثيرات البيولوجية والبيوكيميائية لبعض الفواكه المجفقة على الجرذان المصابة بالفثل الكلوي الحاد البعاد

\author{
علا إبراهيم الاسوقي علي - إنصاف مختار يسن - أسماء عبدالعزيز تمراز \\ طنطا - مصر - قسم التغذية وعلوم الاطعمة ـ كلية الاقتصاد المنزلي- جامعة الأزهر \\ الملخص العربي
}

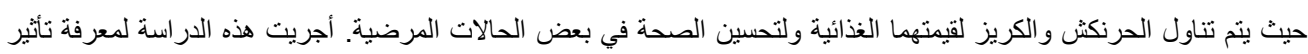

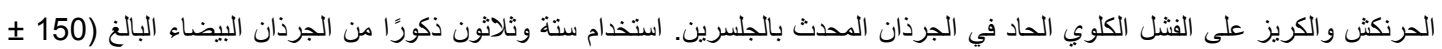

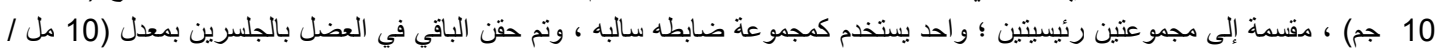

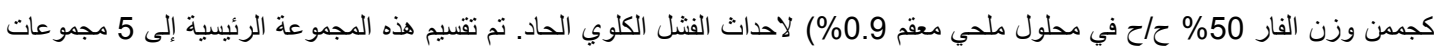

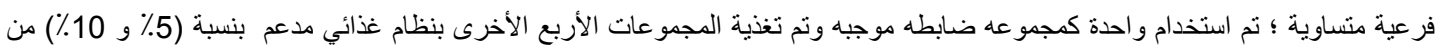

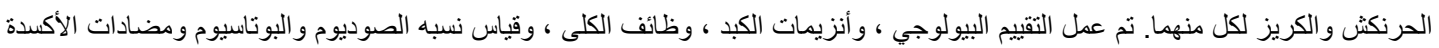

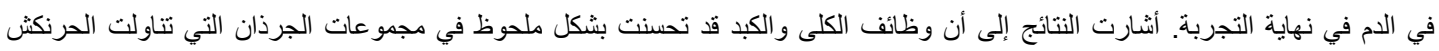

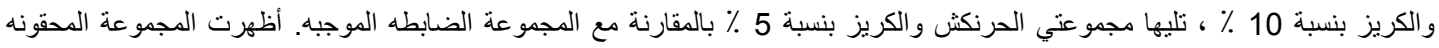

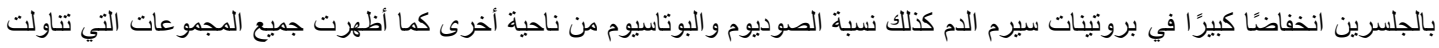

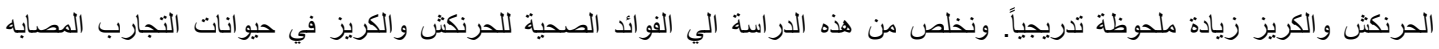

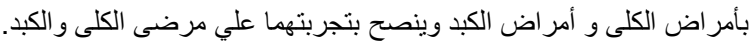

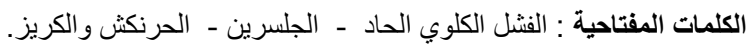

